\title{
INOVASI OLAH PANGAN DARI PISANG DI DESA SUI. BATANG KALIMANTAN BARAT
}

\author{
Food Innovation from Banana in Sui Village. Batang West Kalimantan
}

\author{
Desdy Hendra Gunawan dan Ridwan Salim \\ Politeknik Negeri Pontianak, Jurusan Teknologi Pertanian dan Budidaya Perikanan, \\ Jalan Jenderal Ahmad Yani Pontianak, Kalimantan Barat \\ Korespondensi penulis, Email: desdy24@yahoo.co.id
}

\begin{abstract}
Banana is a local commodity in Sui Village. Batang West Kalimantan which has the potential to be developed in improving the economy of the community. So far the Sui Village community. Batang chose to sell fresh bananas because of the lack of knowledge and skills to process bananas into attractive, quality and economic value food products. Community service activities become the right place for education and skills improvement for rural areas. Individual approaches and simplification of material become methods in the implementation of this activity. Providing information on technology after harvesting bananas, business opportunities and training in processing bananas as an innovation if banana food is expected to shape the Sui Village community. Batang who is creative, innovative and productive in empowering the potential of local commodities. Sui Village Community. Batang who has deep skills as an innovation in banana food is an effort to reach a prosperous society.
\end{abstract}

Keywords: innovation of food, local commodities, banana, post-harvest

\begin{abstract}
ABSTRAK
Pisang merupakan komoditi lokal Desa Sui. Batang Kalimantan Barat yang berpotensi untuk dikembangkan dalam meningkatkan ekonomi masyarakat. Selama ini masyarakat Desa Sui. Batang memilih menjual pisang segar karena kurangnya pengetahuan dan ketrampilan untuk mengolah pisang menjadi produk pangan yang menarik, berkualitas dan bernilai ekonomi. Kegiatan pengabdian kepada masyarakat menjadi wadah pendidikan dan peningkatan ketrampilan yang tepat bagi daerah pedesaan. Pendekatan individu dan penyederhanaan materi menjadi metode dalam pelaksanaan kegiatan ini. Memberikan informasi teknologi pasca panen pisang, peluang usaha dan pelatihan dalam mengolah pisang sebagai inovasi olah pangan pisang diharapkan dapat membentuk masyarakat Desa Sui. Batang yang kreatif, inovatif dan produktif dalam memperdayakan potensi komoditi lokal. Masyarakat Desa Sui. Batang yang memiliki ketrampilan dalam sebagai inovasi olah pangan pisang merupakan usaha untuk mencapai masyarakat yang sejahtera.
\end{abstract}

Kata Kunci: Inovasi olah pangan, komoditi lokal, pisang, pasca panen

\section{PENDAHULUAN}

Kabupaten Mempawah salah satu Kabupaten yang terletak di propinsi Kalimantan Barat. Kabupaten Mempawah terdiri dari 9 kecamatan, yang diantaranya adalah Kecamatan Sungai Pinyuh. Kecamatan Sungai Pinyuh sebagai bagian dari Kabupaten Mempawah berperan besar dalam menunjang perkembangan sektor pertanian. Selain memiliki kekayaan alam yang berpotensi untuk dikembangkan, Kecamatan Sungai Pinyuh juga berkembang dalam perdagangan yang tentunya sangat baik sebagai pangsa pasar bagi produk unggulan daerah. Letak adminitrasi Kecamatan Sungai Pinyuh adalah sebelah utara berbatasan dengan Kecamatan 
Anjongan, sebelah timur berbatasan dengan Kecamatan Segedong Kabupaten Landak, sebelah barat berbatasan dengan Kecamatan Mempawah timur dan sebelah selatan berbatasan dengan laut Natuna. Desa Sei. Batang merupakan salah satu Desa yang terletak di Kecamatan Sungai Pinyuh yang mengembangkan sektor pertanian dan perkebunan.

Desa Sei Batang adalah sebuah desa bagian Kecamatan Sungai Pinyuh, Kabupaten Mempawah Kalimantan Barat yang berjarak $48 \mathrm{KM}$ dari Kota Pontianak. Desa ini tercatat memiliki warga 1018 lakilaki dan 975 warga perempuan dengan pekerjaan umum adalah petani dan ibu rumah tangga. Berdasarkan data profil Desa Sei Batang tahun 2016 wilayah perkebunan pisang yang dimiliki seluas $115 \mathrm{Ha}$ dengan tanaman pisang 43,12 Ha dan sisanya nanas, jambu, ubi kayu dan buah naga. Produk hasil perkebunan Desa Sei. Batang selama ini dijual dalam bentuk segar ke penadah atau dijual kepasar terdekat dengan harga jual rendah. Tidak adanya pengetahuan dan ketrampilan pengolahan pasca panen menjadi alasan petani menjual produk komoditi lokal dalam bentuk segar. Peluang bagi warga masyarakat Desa Sei. Batang yang dapat diciptakan dalam memanfaatkan potensi hasil perkebunan yaitu buah pisang menjadi souvenir cantik manis khas desa Sei Batang dalam olahan selai pisang, keripik manis pisang, nugget pisang, cake piang dan abon jantung pisang. Harapan tersebut menjadi tujuan dalam kegiatan pengabdian pada masyarakat (PKM) yang dilakukan di Desa Sui. Batang.

Mumtaz et al. (2010) menyimpulkan pisang dan olahannya aman untuk penderita mag, sedangkan Kumar et al. (2012) menyebutkan bahwa buah pisang mengandung sejumlah nutrisi yang terpenting bagi tubuh, utamanya adalah vitamin C. Pisang juga kaya akan serat sehingga baik untuk sistem pencernaan (Bhaskar et al., 2011). Kandungan gizi yang terkandung dalam pisang tentunya menjadi nilai lebih pada produk olahan pisang sehingga pisang layak dijadikan produk olahan.

Permasalahan dasar masyarakat Desa Sui. Batang yaitu tidak memiliki kemampuan sumber daya manusia dalam mengolah pisang yang merupakan komoditi lokal. Selain itu motivasi dan jiwa wira usaha belum berkembang dalam diri masyarakat Desa Sui. Batang karena minimnya kemampuan melihat potensi pangsa pasar dan potensi pengembangan produk olahan pisang.

\section{BAHAN DAN METODE}

\section{Bahan dan alat}

Bahan yang digunakan adalah buah pisang yang sudah matang, jantung pisang, bahan tambahan dan bumbu penyedap produk. Pada kegiatan PKM digunakan alat produksi salai selai pisang, keripik manis pisang, nugget pisang, cake pisang dan abon jantung pisang serta alat pengemasan. Peralatan produksi yang digunakan pada pelatihan pembuatan produk diserahkan kepada mitra PKM sebagai modal dalam pengembangan produk.

\section{Metode}

Metode pada kegiatan PKM dilakukan tiga tahapan pelaksanaan, yaitu : 1) pendekatan dan diskusi dengan pengurus masyarakat (mitra PKM) setempat untuk mengetahui cara komunikasi yang tepat dalam kegiatan PKM. 2). Penyampaian materi teoritis tentang pisang, produk olahan pisang dan kewirausahaan. 3). Pelatihan pembuatan produk olahan pisang. Mitra PKM yang mengikuti pelatihan dibatasi 20 peserta.

\section{HASIL DAN PEMBAHASAN}

Mitra PKM mengikuti kegiatan PKM dengan antusias. Hal tersebut terlihat dari jumlah peserta yang mengikuti kegiatan hingga selesai adalah $100 \%$ dan keaktifan mitra PKM selama kegiatan PKM. Produk olahan pisang yang dilatihkan untuk 
diproduksi dalam kegiatan PKM berupa selai pisang, keripik manis pisang, nugget pisang, cake pisang dan abon jantung pisang dapat dibuat dan dikemas oleh mitra PKM saat pelatihan pembuatan produk dengan baik. Berdasarkan hasil kuisioner yang diisi oleh mitra PKM setelah pelaksanaan PKM tentang produk olahan pisang yang dibuat, yaitu dapat dikembangkan dan berpotensi untuk dijual dapat tertera pada Tabel 1 .

Tabel 1. Produk yang dapat dikembangkan dan berpotensi untuk dijual

\begin{tabular}{lccc}
\hline \multicolumn{1}{c}{ Produk } & Ya & Tidak & Total \\
\hline Selai pisang & 5 & 15 & 20 \\
Keripik manis pisang & 18 & 2 & 20 \\
Nugget pisang & 17 & 3 & 20 \\
Abon jantung pisang & 15 & 5 & 20 \\
Cake pisang & 14 & 6 & 20 \\
\hline
\end{tabular}

Mitra PKM berpendapat keripik manis pisang lebih menarik untuk dikembangkan dan bernilai jual yaitu dengan $90 \%$ menyatakan "ya". Selai pisang dinilai kurang dapat dikembangkan dan kurang berpotensi untuk dijual, yaitu dengan $5 \%$ menyatakan "ya". Nugget pisang menjadi urutan kedua terbaik yang dipilih mitra PKM untuk dapat dikembangkan dan dijual yaitu $85 \%$ memilih "ya". Kemudian abon jantung pisang dinilai $75 \%$ dan cake pisang $70 \%$ dinilai mitra PKM dapat dikembangkan dan berpotensi untuk dijual (tabel. 1).

Pengisian kuisioner ini melatih mitra PKM untuk jeli melihat potensi pengembangan produk dan pangsa pasar. Mitra PKM memilih produk olahan pisang berdasarkan tampakan fisik (tekstur, warna), rasa, cara mengkonsumsi, pengemasan produk dan kemudahan menjual. Produk selai pisang menjadi yang paling sedikit peminat untuk dikembangkan dan dijual yaitu 5\%, karena pengemasan jenis plastik kurang menarik untuk produk selai dan tidak dapat langsung dikonsumsi (bahan tambahan mengkonsumsi roti).

Keripik pisang, nugget pisang dan abon jantung pisang menarik dalam pengemasan plastik yang disealer, menarik tampakan fisik dan citra rasanya. Keripik manis pisang menjadi yang paling diminati untuk dikembangkan dan dijual dari pada nugget pisang dan abon jantung pisang padahal sama menarik dalam kemasan dan citra rasa. Kondisi tersebut lebih disebabkan keripik manis pisang karena lebih mudah dikonsumsi sebagai cemilan yang dapat dikonsumsi dimana saja dan kapan saja dibandingkan abon dan nugget yang dikonsumsi pada saat makan nasi. Untuk cake pisang mitra PKM menilai berpotensi untuk dikembangkan dan dijual sebagai cake rasa khas pisang yang merupakan komoditi lokal daerah Desa Sui. Batang. Cake pisang dapat disajikan saat kumpul keluarga, acara, hari raya dan di warung kopi yang tersebar di Kecamatan Sungai Pinyuh.

Hasil produk yang dibuat mitra PKM saat pelaksanaan kegiatan PKM dapat dilihat pada Gambar 1 sampai Gambar 3.

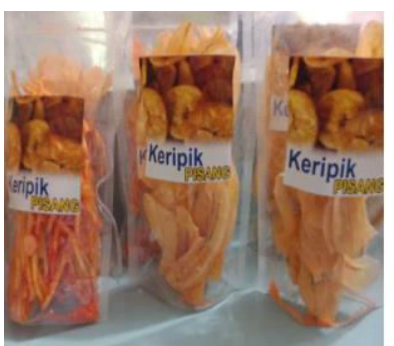

Keripik manis pisang

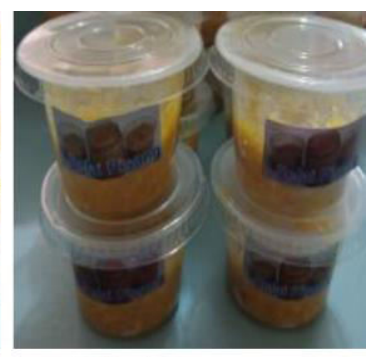

Selai pisang
Gambar 1. Produk keripik manis pisang dan selai pisang

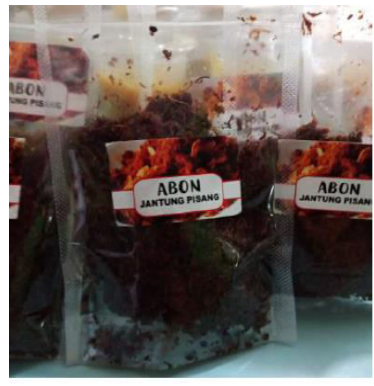

Abon jantung pisang

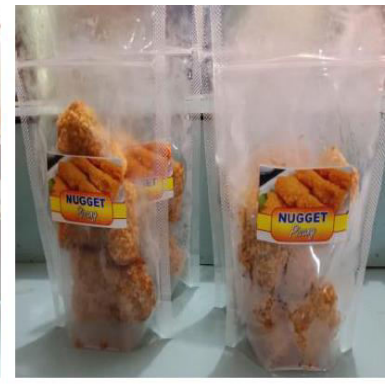

Nugget pisang
Gambar 2. Produk abon jantung pisang dan nugget pisang 


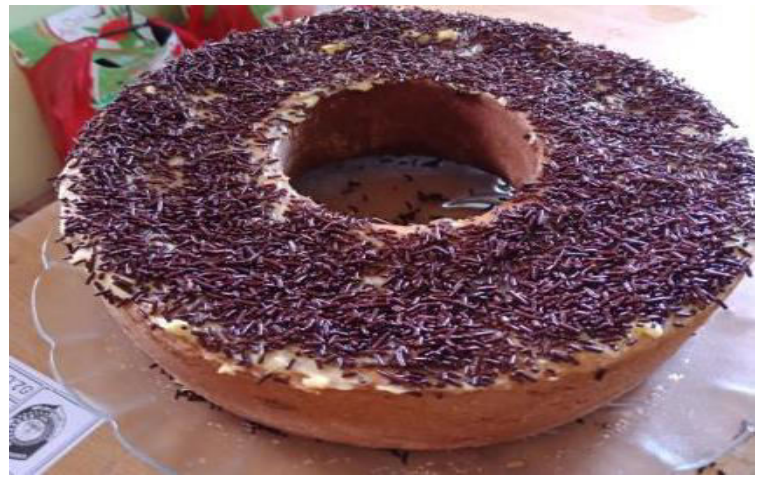

Gambar 3. Produk cake pisang

\section{KESIMPULAN}

Setelah kegiatan PKM dilaksanakan, dapat disimpulkan:

1. Kegiatan PKM terlaksana dengan baik.

2. Mitra PKM terampil membuat produk olahan pisang.

3. Mitra PKM potensial dalam pengembangan produk dan melihat potensi pasar.

4. Produk keripik manis pisang, nugget pisang, abon jantung pisang dan cake pisang potensial untuk dikembangkan dan dijual.

\section{UCAPAN TERIMA KASIH}

Pelaksana PKM dan mitra PKM mengucapkan terima kasih yang sebesarbesarnya kepada Kemenristek Dikti yang telah memberi dana pelaksanaan kegiatan PKM di Desa Sui. Batang Kecamatan Sungai Pinyuh Kabupaten Mempawah Kalimantan Barat.

\section{DAFTAR PUSTAKA}

Bhaskar, J.J., Chilkunda, N.D., \& Salimath, P. V. (2011). Banana (Musa sp. var. elakki bale) flower and pseudostem: dietary fiber and associated antioxidant capacity. Journal of Agricultural and Food Chemistry, 60(1), 427-432.

Mumtaz, J., Warsi, M. K., \& Fehmeeda, K. (2010). Concentration influence on antimicrobial activity of banana blossom extract-incorporated chitosanpolyethylene glycol (CS-PEG) blended film. Journal of Chemical and Pharmaceutical Research, 2(5), 373378.

Kumar, K. S., Bhowmik, D., Duraivel, S., \& Umadevi, M. (2012). Traditional and medicinal uses of banana. Journal of Pharmacognosy and Phytochemistry, 1(3), 51-63. 